\title{
Internal System of Quality Management in the Context of Ensuring the Quality of Preparation of Managers for Future Practice
}

\author{
Roman Hrmo ${ }^{1}$, Lucia Krištofiaková ${ }^{1}$, Silvia Barnová ${ }^{1}$ \\ 1DTI University, Slovakia
}

\begin{abstract}
In the presented paper, the authors deal with the internal system of quality management as a means of ensuring the quality of managers' preparation for their future practice at universities. They introduce the internal system of quality management at a university, Bachelor's and Master's study programmes in Management, the study programme graduate profile, as well as activities and methods related to ensuring the quality of study programmes, i.e. to preparation of managers for their future practice. The authors focus on the process of internal audits, evaluation of university study programmes (including the evaluation of university courses based on study results, classroom observations, feedback from students, feedback from employers, evaluation of feedback from graduates and their success; evaluation of scientific research work in the particular field of science), risk analysis, the "Bank of Proposals" and assessment of the internal system of quality management by the university's management. In the paper, the authors provide examples of good practice from the discussed field, too.
\end{abstract}

Keywords: internal system of quality management, university, study programme, manager, practice

\section{Introduction}

It is very important to prepare graduates for future practice. In order to offer the best possible education and prepare university graduates for the labour market, we attempt to permanently improve the university's quality. In practice, a complex approach - an 
internal system of university quality management as a means of ensuring the quality of preparation of managers for their future practice - showed to be effective.

Those who want to hold the position of a manager in the future, can study management at DTI University in Bachelor's and Master's study programmes.

The Bachelor's study programme in Management provides students with theoretical and practical preparation for the job position of a Junior Manager. The graduates are prepared for working in the divisions of planning, human resources, finances, financial-economic analyses, production and logistics, marketing, accounting, informatics and controlling, and can find employment in all branches of entrepreneurship both in the public and the non-governmental spheres. The professional profile of Bachelor's study programme graduates in Management contains the following:

- are able to present their own opinions and working proposals to the team of coworkers and also to their superordinate,

- can manage a group of people, plan, organize, coordinate, motivate, lead and control the work of a working group,

- can apply elements of psychology, sociology, and ethics in managing a group of people,

- can hold a job position in the divisions of planning, human resources, finances, financial-economic analyses, production and logistics, marketing, accounting, informatics and controlling,

- can apply knowledge and skills in all branches of both the public and the nongovernmental spheres,

- $\quad$ are prepared to study at the second level of university education (earn a Master's degree - Mgr. or Ing. - Senior Manager).

The Master's study programme in Management contributes to the development of knowledge in Management, Economics, and Economy, with an emphasis placed on modern trends in Management. The professional graduate profile is as follows:

In accordance with the achieved level, the graduates are eligible to work as Senior Managers. A Senior Manager - a Master of Management - knows the additional functions of management and can see management problems in a broader context; after some practice, is able to manage groups of people within an organization (business or institution) on division or organization (business or institution) levels; possesses complex knowledge about the organization (business or institution).

During their studies, graduates acquire theoretical knowledge and develop they practical skills and abilities:

Theoretical knowledge:

- possess deeper knowledge from the basic fields of Management and Informatics,

- understand and master the knowledge from special management disciplines,

- possess knowledge from supporting management disciplines. 
Practical skills and abilities:

- are able to manage large groups of people, plan, organize, lead and control the work of large working groups,

- are able to hold a managerial job position in the divisions of planning, human resources, finances, financial-economic analyses, production and logistics, marketing, accounting, informatics and controlling,

- are able to manage and coordinate the work of several large working groups or an entire organization (business or institution),

- the acquired knowledge and skills enable them to find employment in all branches of entrepreneurship, including budgeting.

Additional knowledge, skills, and abilities:

- can use more complex applications of corporate information systems,

- can use communication technologies developed for large groups of people,

- can deal with enormous workload and are able to regenerate.

University education, research and innovation have a big role to play in the promotion of social cohesion, economic growth, and global competition. Given by the joint efforts of European countries to focus more and more on knowledge, university education has become an integral part of socio-economic and cultural development. The growing demand for skills and competencies brings the need for new reactions to situations by universities (ESG, 2015).

Ensuring quality is a topical issue in university environments. We consider the introduction of an internal system of university quality management an appropriate way of quality assurance.

Quality of schools can be theoretically defined as the desired, optimal level of schools' and their products' functioning. Especially in the conditions of market economies, where schools are considered a public service, and students and their parents are the schools' clients, it applies that the achieved quality of a school is decisive from the aspect of its successful existence (Průcha, Walterová and Mareš, 2003).

Turek (2015) claims that every school should work out its own quality management system, which should cover all the processes within the school, as well as the whole personnel.

As mentioned by Paulová (2009), increasing the quality of the educational process is among the requirements of the Bologna Process and Lisbon Strategy accepted by all EU member states - including Slovakia. A continuous improvement of processes in a way, which is beneficial for customers and all the stakeholders, should become the strategic goal of each organization.

In a long term, our activities focus on the issues of the evaluation of quality and the opportunities to improve the quality in the context of educational organizations. We are aware of the current need for improving the quality of schools and the quality of the 
educational process itself. It is important to focus on schools' partners and their requirements, on students' personality development, development of their key competencies, and to reflect the requirements from practice.

The above statements are confirmed in the work by authors focusing on the presented issues (Kučerka, 2018; Szőköl and Horváth, 2018; Berková et al., 2019, 2016; Tureková, Bánesz and Depešová, 2015, 2014; Hašková, Lukáčová and Noga, 2019).

In the context of managers' preparation for their future practice, in agreement with Lajčin et al. (2014), Kmecová and Smetanová $(2019,2018)$, we consider important to pay sufficient attention to the preparation of future managers at universities.

Alongside with the issues of the realization of activities and methods, we draw attention to their evaluation. We agree with Bilč́k (2017), who declares that the basic precondition for an organization's success (university in our case) is a systematic evaluation of the achieved results. In order to improve, universities should learn about the current situation in the institution, know how individual processes are carried out, and what the university's strengths and weaknesses, as well as its opportunities and threats are.

In accordance with the above, in the following parts of the paper, we deal with the internal system of university quality management, as well as activities and methods related to ensuring the quality of the offered study programmes, including the preparation of managers for their future practice.

\section{Methods and Data}

We apply a complex approach to ensuring the university's quality. Our university has introduced and applies a management quality system in accordance with ISO 9001:2015 standard in the field: Education at all levels of university education and for the related scientific research and publication work. The results of certification audit showed that the management system fulfils all the requirements of the above norm and the university has been certified by QSCert, spol. s r. o., which confirms that the introduction and application of the management quality system are in accordance with ISO 9001:2015 standard requirements in the above field.

The university, in compliance with the criteria of the Internal system of ensuring the quality of university education (KVSK); Law No. 131 on Higher Education and on Changes and Supplements to Some Laws ( $(87 \mathrm{a}$ ); in compliance with the Standards and guidelines for quality assurance in the European Higher Education Area (ESG); and ISO 9001:2015 standard, defines the integrated Internal system of ensuring quality and the System of quality management, its policy, quality objectives and procedures in the Quality Manual and the related organizational standards.

The main objective of the internal system of quality is to focus on quality and its assurance within the university's activities. 
We consider a complex approach to all the processes realized within the university an important step from the aspect of achieving success, and the graduates' preparedness for practice.

Our university's internal system of quality management is process-controlled. The controlled processes are divided into three categories which were identified based on their relation to the mission of the university and the provided services:

- main procedures - educational process, editorial and publication work, and scientific research work,

- managerial procedures - strategic management, personnel quality management, education infrastructure management, marketing and communication, documentation and record management, and improving the internal system,

- auxiliary procedures - library services, scholarships, and mobilities.

All the processes and procedures required by law are documented in the Quality Manual, the Cards of Procedures (CP) and other related documentation. In the field of documentation management, uniform practices are employed. There are also procedures for keeping records about the state of the internal system of university management, about its compliance with the requirements and procedures of continuous improvement.

In the presented paper, it is not possible to cover all the issues of school quality management. So, we focus on the internal system of quality, we deal with selected activities and methods, which are closely related to the quality assurance of study programmes and preparation of managers for their future practice.

For providing high-quality education and preparation of graduates for practice, in a functioning internal system of quality, we find it important to carry out internal audits, evaluate study programmes (evaluation of university courses based on study results, classroom observations, feedback from students, evaluation of feedback from employers, evaluation of feedback from graduates and their success, evaluation of scientific research work in the particular field of science), carry out risk analysis, have a "Bank of Proposals" and to evaluate the internal system of quality management by the university's management.

\section{Results}

In the below part of the paper, we present the results of the implementation of activities and methods related to the quality assurance of study programmes including the preparation of managers for their future practice. In this part of the paper, we provide examples of good practice in relation to the realization of the above activities and methods verified in practice.

We focus on the issues of internal audit, evaluation of study programmes, risk analysis, and the "Bank of Proposals". 


\section{Internal audits}

One of the tools for ensuring high-quality manager preparation for future practice is carrying out internal audits. The aim of internal audits in educational institutions is to assess the level of compliance between the process and documentation of the system of quality, and the requirements of ISO 9001:2015 standard in practice, to review the efficiency of the system of quality and its functioning, and to improve the system of quality and its documented procedures. Internal audits focusing on the quality of the university are carried out by trained (certified) auditors, while internal audits can be carried out by suppliers as well.

Internal audits are carried out in three steps:

- preparation of the internal audit,

- realization of the internal audit,

- evaluation of the internal audit.

The process of internal audits is illustrated in Table 1.

Tab. 1: Stages of internal audit realization

\begin{tabular}{|l|l|}
\hline Stage & Quality assurance procedures \\
\hline Preparation of internal audit & $\begin{array}{l}\text { Preparation of the Programme of internal audit. It contains: } \\
\text { the aim of the audit, } \\
\text { identification of the head of the audit team and its members, } \\
\text { identification of the required documents, which must be available } \\
\text { during the audit, } \\
\text { date and place of the audit, } \\
\text { estimated time and duration of the audit, including the timetable } \\
\text { of the internal audit. }\end{array}$ \\
\hline Realization of internal audit & $\begin{array}{l}\text { Internal audits begin with informing the audited about the content of } \\
\text { the internal audit. } \\
\text { Subsequently, the audit team collects evidence (e.g. by means of } \\
\text { interviews, examining documents, etc.). } \\
\text { Significant signs of discrepancies are investigated. The findings and } \\
\text { evidence are recorded in the Control Sheet. } \\
\text { The realization of internal audits ends with a closing session with the } \\
\text { audited, the purpose of which is to inform them about the found } \\
\text { discrepancies. }\end{array}$ \\
\hline $\begin{array}{l}\text { Auditors work out the Protocol for Internal Audit. If there are any } \\
\text { suggestions for improving the internal system of quality management, } \\
\text { they must be stated in the Protocol. } \\
\text { The head of the audit team submits the Protocol for Internal Audit to } \\
\text { the Vice-Rector within 3 working days following the internal audit. The } \\
\text { Protocol must be signed by the audited, which is a proof of admitting } \\
\text { the found discrepancies. }\end{array}$ \\
\hline
\end{tabular}

Source: Authors.

\section{Evaluation of study programmes}

The management of DTI University has created a formal and effective system of study programme evaluation carried out once a year. They have set the timetable for evaluation 
and the goals for a further increase in the quality of study programmes. It applies both internal and external sources of evaluation.

The evaluation process of study programmes consists of:

- evaluation of university courses based on study results, classroom observations, feedback from students,

- evaluation of feedback from employers,

- evaluation of feedback from graduates and their success,

- evaluation of scientific research work at the workplace in a particular field of science (Hrmo, 2014).

In the context of the evaluation of study programmes, we provide an example of good practice with using feedback from students.

In the Bachelor's study programme in Management (external form of study), students take the following obligatory courses:

Marketing, Corporate Economics, Law I, Mathematics, Macroeconomics, Management, Statistics for Managers, Finances and Currency, Microeconomics, Informatics for Managers I, Basic Accounting, National Economy, Controlling, Project Management, Human Resources Management, Financial-Economic Analysis, Corporate Finance, General Psychology, Operational Management, International Economic Relations, Informatics for Managers II, Management Information Systems, Manager's Personality Psychology, Seminar for Bachelor's Thesis, Entrepreneurship in SMEs.

In the context of the evaluation of study programmes and of university teachers' quality, aiming to permanently improve education, DTI University collects feedback from students on university courses and the work of teachers by means of an anonymous questionnaire survey after finishing each semester (twice year) in the Modular Academic Information System MAIS.

Evaluation by students is focused on the bellow aspects within which further sub-fields are evaluated:

- educational content of university courses and their implementation into the study programme,

- organization of education,

- evaluation of study results,

- staffing of university courses,

- availability of literature,

- the educational process - forms and methods,

- spatial and technical equipment.

Within the survey, students are provided with space for listing the most serious issues related to their studies, as well as their suggestions for improvement. They can also indicate what would contribute to increasing the quality of education. 
In the process of evaluation, the following scale is applied: excellent (value 1), very good (value 2), good (value 3), satisfactory (value 4), not satisfactory (value 5).

In the questionnaire, the following data are identified: university course, teacher, students' gender, form of study, level of university study, year of study. Based on it, measures for improving the quality of particular university courses, years of study, etc. are taken.

\section{Risk analysis}

In the context of ensuring and increasing the quality of processes, the university carries out risk analyses - considers the external and internal factors of the environment, the stakeholders' requirements and expectations and determines risks and opportunities, which should be paid attention to.

In this part of the paper, we present the partial results of a risk analysis of the educational process as an example of good practice. Among the external factors, we can mention, e.g. accreditation requirements, legislation in force, competition - other universities, interest of potential students, declining demographic curve; internal factors, such as the university's system of management, number of students, preparedness of students, expertize and incentive of the personnel, personnel changes; stakeholders - e.g. partner universities (in Slovakia and abroad), Slovak state administration bodies, DTI University students, potential students, employers, the Slovak Accreditation Agency for Higher Education; requirements of stakeholders - e.g. high-quality education, demanded study programmes, school equipment, high-quality teachers, teachers' approach, organization of the educational work, etc. An example of identifying the degree of risk of possible errors for the process Education is showed in Table 2.

Tab. 2: Identification of the degree of risk of possible errors for the process Education

\begin{tabular}{|l|l|c|c|c|}
\hline $\begin{array}{l}\text { Name of the process } \\
\text { step }\end{array}$ & Possible errors & $\begin{array}{c}\text { Probability } \\
\text { of occurance } \\
\text { (PO) }\end{array}$ & $\begin{array}{c}\text { Seriousness of } \\
\text { consequences } \\
\text { (SC) }\end{array}$ & $\begin{array}{c}\text { Degree } \\
\text { of risk }\end{array}$ \\
\hline $\begin{array}{l}\text { Creation and } \\
\text { accreditation of study } \\
\text { programmes }\end{array}$ & $\begin{array}{l}\text { Incomplete } \\
\text { information in the accreditation } \\
\text { file of the study programme }\end{array}$ & 1 & 3 \\
\hline $\begin{array}{l}\text { Organization of the } \\
\text { academic year }\end{array}$ & $\begin{array}{l}\text { Missing or incorrect } \\
\text { information in the academic } \\
\text { yeartimetable }\end{array}$ & 1 & 2 & 2 \\
\hline $\begin{array}{l}\text { Organization of the } \\
\text { educational work }\end{array}$ & $\begin{array}{l}\text { Duplicity in classrooms in } \\
\text { which teaching should take } \\
\text { place at particular time }\end{array}$ & 2 & 2 \\
\hline Final thesis & $\begin{array}{l}\text { The published theme of the } \\
\text { final thesis is not in compliance } \\
\text { with the focus of the study } \\
\text { programme }\end{array}$ & 2 & 6 \\
\hline
\end{tabular}

Source: Authors.

The probability of occurrence (PO) is given by the university on the scale ranging from 1 to 3 ( 1 - lowest PO, 3 - highest PO), seriousness of consequences (SC) on the scale ranging from 1 to 3 ( 1 - lowest SC, 3 - highest SC). The degree of risk is calculated by multiplying 
PO and SC. The university has set the limit value for risk 6, which means that if the degree of risk reaches 6 , measures will be taken. In the example of good practice above, in order to eliminate the possible error occurring with final theses, it is important to take measures.

\section{Bank of Proposals}

An additional source of information from students and personnel is the "Bank of Proposals", by means of which students and personnel can express their opinions. In the entrance of the university building, at a visible place, a mailbox functioning as a "Bank of Proposals", where students and personnel can write their suggestions, proposals, comments, and recommendations, is placed.

The "owner" of the process "Improving the DTI University's internal system of quality" checks the content of the "Bank of Proposals" regularly (once a month). The proposals by the university's students and personnel are dealt with and solved by the owners of particular processes.

\section{Discussion}

By monitoring and evaluating the effectiveness of the system of quality and the relevance of the university's principles in the field of quality (including the activities and methods related to the quality assurance of study programmes mentioned in the paper, i.e. also the managers' preparation), the Internal system of quality management is evaluated by the university's management.

In order to assess the system of quality, the Vice-Rector for Quality and Development in cooperation with the responsible owners of the processes carries out an evaluation of the DTI University's Internal system of management quality in the extent of the following outputs:

- evaluation of the offered study programmes' quality and feedback from the participants of education,

- evaluation of scientific research work related to the field of research and innovation of study programmes based on the results of scientific research work,

- evaluation of the quality and development of the teaching staff,

- internal audit of processes and of the whole system,

- evaluation of the productivity of suppliers,

- evaluation of arguments and complaints, and the results of internal control,

- the effectiveness of corrective and preventive activities, the effectiveness of measures taken for managing risks and opportunities,

- evaluation of process performance,

- examining the extent to which the set goals have been fulfilled and the policy of Internal system of DTI University's quality management, 
- changes in the external and internal factors of the environment, which can have an impact on the system of quality management,

- feedback from relevant stakeholders,

- appropriateness of resources

- corrective measures and measures for managing risks and opportunities for improving the system of quality management.

The results of the evaluation process form a part of the Report on the evaluation of the Internal system of quality management by the university's management. The report is submitted to the DTI University's Quality Committee by the Vice-Rector. The Quality Committee discusses the report and takes action for further improvement of the system. The result of quality assessment by the Quality Committee are reflected in the following outputs (corrections in the Internal system of quality management):

- setting qualitative goals for the upcoming period,

- possible corrections in quality policy,

- suggestions of corrective measures and measures for managing risks and opportunities related to the problem fields indicated in the report on the functioning and efficiency of the system of quality,

- identification of resources necessary for the realization of the goals and taking measures for the upcoming period.

\section{Conclusion}

Ensuring the quality of the preparation of university graduates for their future practice is a demanding process, which requires a complex approach. An example of such an approach is the introduction of internal system of quality management and its proper functioning. The length of the paper did not allow us to offer a complex elaboration of the internal system of university quality management. We focused on selected tools and methods related to the preparation of graduates in the study programme Management for their future practice. We pointed out the process of realization of internal audits, evaluation of study programmes, mainly in relation to feedback from students, risk analysis, the "Bank of Proposals" and examining the internal system of quality management by the university's management. The paper includes examples of good practice confirming the importance of dealing with the issues of permanent improvement of the quality of universities.

\section{Acknowledgement}

The authors gratefully acknowledge the contribution of the KEGA Grant Agency of the Slovak Republic under the KEGA Project 014UKF-4/2020 „Innovative learning e-modules for safety in dual education". 
We also acknowledge the support of Erasmus+ project ENTER - EngineeriNg educaTors pEdagogical tRaining (Project Reference: 598506-EPP-1-2018-1-PT-EPPKA2-CBHE-JP).

\section{References}

BERKOVÁ, K. et al., 2019. Future economic professionals: development of practical skills and competencies in higher education from the point of view of international employers. Economic Annals-XXI, 176(3-4), p. 91-98. ISSN 1728-6220.

BILČÍK, A. , 2017. Posudzovanie a hodnotenie úrovne vzdelávania [Assessment of the level of education]. Krpálek, P., Krpálková Krelová, K. (editors). Autoevalační kultura a kvalita vzdělávaní. Sborník recenzovaných př́spěvků mezinárodní vědecké konference. [The culture of self-evaluation and the quality of education. Book of proceedings]. Prague: Extrasystem Praha. p. 21-26. ISBN 978-80-87570-36-4.

DEPEŠOVÁ, J. and I. TUREKOVÁ, 2014. Implementation model of teaching practice with the application of a videoconference system. 2014 IEEE 12th International Conference on Emerging eLearning Technologies and Applications (ICETA), Starý Smokovec, Slovakia. p. 91-96. ISBN 978-147997740-6.

HAŠKOVÁ, A., D. LUKÁČOVÁ and H. NOGA, 2019. Teacher's self-assessment as a part of quality management. Science for Education Today, 9 (2), p. 156-169. ISSN 2658-6762.

HRMO, R., 2014. Príručka kvality Dubnického technologického inštitútu v Dubnici nad Váhom (Vnútorný predpis vysokej školy upravujúci vnútorný systém kvality). [Quality Manual of the Dubnica Institute of Technology in Dubnica nad Váhom (Internal regulation of the University on the internal system of quality].

KRPÁLEK, P. and K. KRPÁLKOVÁ KRELOVÁ, 2016. Possibilities for developing business potential in economic education. Examples of implementation in Slovakia and the Czech Republic. Economics and Sociology, 9(4). p. 119-133. ISSN 2071-789X.

KUČERKA, D. and M. KUČERKOVÁ, 2018. Creation of a literary device for the subject management of the work of a car dealer. Proceedings of the 32nd International Business Information Management Association Conference, IBIMA 2018 - Vision 2020: Sustainable Economic Development and Application of Innovation Management from Regional expansion to Global Growth 2018, p. 1536-1543. ISBN 978-099985511-9.

LAJČIN, D. et al., 2014. Sociálna inteligencia ako významný prediktor manažérskeho správania [Social Intelligence as a Significant Predictor of Managerial Behavior]. Ekonomický časopis [Journal of Economics], 62(6), p. 646-660. ISSN 0013-3035.

KMECOVÁ, I., 2019. Entrepreneurial education and teaching methods applied at college. Proceedings of the 33rd International Business Information Management Association Conference, IBIMA 2019 - Education Excellence and Innovation Management through Vision 2020, p. 1660-1668. ISBN 978-099985512-6. 
KMECOVÁ, I. and D. SMETANOVÁ, 2018. Analysis of entrepreneurial potential of university students by Pearson's chi-squared test. Proceedings of the 31st International Business Information Management Association Conference, IBIMA 2018 - Innovation Management and Education Excellence through Vision 2020, p. 1769-1780. ISBN 978099985510-2.

PAULOVÁ, I., 2009. Prístupy k manažérstvu kvality vo vzdelávacích organizáciách/školách [Approaches to quality management in educational organizations/schools]. Bratislava: Metodicko-pedagogické centrum v Bratislave.

PRŮCHA, J., E. WALTEROVÁ and J. MAREŠ, 2003. Pedagogický slovník [Pedagogical Dictionary]. Prague: Portál. ISBN 80-7178-772-8.

SZŐKÖL, I. and K. HORVÁTH, 2019. Introducing of new teaching methods in teaching informatics. Informational competences in educating teachers. The Challenges of the Digital Transformation in Education: Proceedings of the 21st International Conference on Interactive Collaborative Learning (ICL2018), p. 542-551. ISBN 978-3-030-11932-4.

Štandardy a usmernenia na zabezpečovanie kvality v Európskom priestore vysokoškolského vzdelávania (ESG) [Standards and guidelines for quality assurance in the European Higher Education Area (ESG)], 2015. Brussels, Belgium. ISBN 978-80-89354-75-7.

TUREK, I., 2015. Škola a kvalita [Schools and quality]. Bratislava: Wolters Kluwer s. r. o. ISBN 978-80-8168-221-6.

TUREKOVÁ, I. and G. BÁNESZ, 2015. Innovation of the occupational health and safety study programme. Proceedings of 2015 International Conference on Interactive Collaborative Learning (ICL 2015), p. 742-747. ISBN 978-147998707-8.

\section{Contact address of the authors:}

doc. PaedDr. Ing. Roman Hrmo, PhD., MBA, ING-PAED IGIP, Department of didactics of vocational subjects, DTI University, Ul. Sládkovičova 533/20, 01841 Dubnica nad Váhom, Slovakia, e-mail: hrmo@dti.sk

Ing. Lucia Krištofiaková, PhD., ING-PAED IGIP, Department of didactics of vocational subjects, DTI University, Ul. Sládkovičova 533/20, 01841 Dubnica nad Váhom, Slovakia, e-mail: kristofiakova@dti.sk

PaedDr. Silvia Barnová, PhD., Department of school pedagogy and psychology, DTI University, Ul. Sládkovičova 533/20, 01841 Dubnica nad Váhom, Slovakia, e-mail: barnova@dti.sk 